\title{
Usefulness of nutritional indices and classifications in predicting death of malnourished children
}

\author{
ANDRÉ BRIEND, CLARE DYKEWICZ, KRISTA GRAVEN, RAMENDRA N MAZUMDER, \\ BOGDAN WOJTYNIAK, MICHAEL BENNISH
}

\begin{abstract}
The usefulness of nutritional indices and classifications in predicting the death of children under 5 years old was evaluated by comparing measurements of 34 children with diarrhoea who died in a Dhaka hospital with those of 318 patients who were discharged in a satisfactory condition. In a logistic regression analysis mid-upper arm circumference was found to be as effective as other nutritional indices in predicting death. Combinations of different indices did not improve the prediction.

Arm circumference might be preferable to more complex criteria for predicting the death of malnourished children.
\end{abstract}

\section{Introduction}

The first commonly accepted classification of malnutrition, developed by Gomez et al in 1956, was derived from measurements of children in hospital. ${ }^{\prime}$ It classified children by weight as a percentage of the median weight of North American children of similar ages. As children in the lowest category of weight for age (less than $60 \%$ of the median) had the highest mortality Gomez et al

International Centre for Diarrhoeal Disease Research, Bangladesh

ANDRÉ BRIEND, MD, international research associate and nutritionist, ORSTOM, France

RAMENDRA N MAZUMDER, MB, BS, medical officer

BOGDAN WOJTYNIAK, SCD, scientist

MICHAEL BENNISH, MD, international research associate and clinical assistant professor in pediatrics, University of Chicago

Department of Pediatrics, University of Chicago

CLARE DYKEWICZ, MD, senior resident, department of paediatrics RISTA GRAVEN, MD, medical student suggested that this classification had prognostic value, and it subsequently became the standard method of assessing malnutrition. It became apparent, however, that children with the same degree of malnutrition might have different clinical features. New classification schemes, using combinations of weight for height, height for age, and the presence of oedema, were then proposed..$^{2-6}$ They were more elaborate and less practical, yet they shared common weaknesses with the Gomez scheme-namely, the cut off points used to determine degrees of malnutrition were still arbitrary, and the usefulness of such schemes in predicting patient outcome was not fully evaluated.

We evaluated the validity of different nutritional indices and classifications for predicting the death of children with diarrhoea admitted to hospital. Arm circumference and arm circumference for age were included among the possible predictors.

\section{Patients and methods}

We conducted the study in the inpatient ward of the Dhaka hospital of the International Centre for Diarrhoeal Disease Research, Bangladesh, which is attended annually by about 70000 people with diarrhoea. Most are children from slum areas with a high prevalence of malnutrition. Those without complications of their diarrhoeal illness are treated as outpatients, and those whose only complication is dehydration are treated in a short stay treatment centre with 150 beds. Patients with more severe illnesses, who constituted the population used for the study, are admitted to an inpatient ward with 50 beds.

For six consecutive months two of the physician investigators (CD, KG), when on duty, enrolled in the study and made anthropometric measurements on all patients under the age of 5 who were admitted to the inpatient ward. Weight, corrected for dehydration if necessary, was measured to the nearest $10 \mathrm{~g}$. The scales used for weighing were calibrated every morning. Height was measured to the nearest $\mathrm{mm}$ when the children were supine. Mid-upper middle arm circumference was measured with a plastic tape, also to the nearest $\mathrm{mm}$. The presence of oedema was determined by applying 
pressure for 30 seconds to the pretibial region. Hydration state was assessed by clinical examination and classified according to World Health Organisation criteria. ${ }^{8}$ Ocular symptoms of vitamin A deficiency, flaking skin, and angular stomatitis were also noted. The date of birth was rarely known precisely but was estimated to the nearest month for every patient from a careful interview with the mother. Tables produced by the National Center for Health Statistics (NCHS) were used to determine weight for age, weight for height, and height for age. ${ }^{9}$ The ratio of arm circumference to age was calculated from Jelliffe norms. ${ }^{10}$

Altogether 455 children were examined, representing about one fifth of all admissions during this period in the inpatient ward. The data on 34 children who died in the hospital were compared with those of children who were discharged alive. Ninety seven children who left the hospital before their diarrhoea was completely cured or who were transferred to another hospital were excluded from the final analysis after ensuring that this did not significantly affect the assessment of the risk of death with the different anthropometric indicators. Six patients whose height was less than the minimum in the NCHS tables $(49 \mathrm{~cm})$ for the calculation of weight for height were also excluded. The final control group comprised 318 children who left the hospital in a satisfactory condition.

The association between nutritional state and risk of death was assessed by logistic regression analysis. ${ }^{11}$ Regression coefficients were estimated with the Walker-Duncan procedure in a program designed for microcomputers. ${ }^{12}$

\section{Results}

The mean age of patients who died was 18 months and that of the control group 21 months; this difference was not significant. Table I shows the mean and SD values of five nutritional indices. The difference in nutritional state between the two groups as measured by any of the indices was significant when tested with an unpaired $t$ test. ${ }^{13}$ There was no significant difference in the prevalence of dehydration, ocular symptoms of vitamin A deficiency, flaking skin, angular stomatitis, or oedema as assessed by a $\chi^{2}$ test. ${ }^{13}$

Table II shows the logistic models describing the relation between different anthropometric indices and the risk of death. All these models were significant - that is, for all indices the risk of death increased when nutritional state was lower. The Hosmer-Lemeshow value after partition of the data into five risk groups did not show any significant difference between predicted and observed numbers of deaths and survivors for all these models. This suggests that they all fitted the data reasonably well. ${ }^{14}$ The higher proportion of children who died in the top two deciles of risk as determined by arm circumference, arm circumference for age, and weight for age suggests that these indices indentify the risk of death better than weight for height and height for age.

TABLE I-Mean (SD) anthropometric indices of children who died in hospital and those who survived

\begin{tabular}{|c|c|c|c|}
\hline & $\begin{array}{c}\text { Discharged improved } \\
\qquad(\mathbf{n}=318)\end{array}$ & $\begin{array}{l}\text { Died in hospital } \\
\quad(n=34)\end{array}$ & Significance \\
\hline Arm circumference $(\mathrm{cm})$ & $11 \cdot 3(1 \cdot 9)$ & $9.9(1.8)$ & $\mathrm{p}<0.001$ \\
\hline Arm circumference for age $(\%)^{\star}$ & 74 (11) & 65 (12) & $\mathrm{p}<0.001$ \\
\hline Weight for age $(\%) \dagger$ & $60 \quad(15)$ & (12) & $\mathrm{p}<0.001$ \\
\hline Weight for height $(\%) \dagger$ & (8) & $71 \quad(9)$ & $\mathrm{p}<0.05$ \\
\hline Height for age (\%)† & $89 \quad(8)$ & $86 \quad(7)$ & $\mathrm{p}<0.05$ \\
\hline
\end{tabular}

$\star \%$ Of Jelliffe norms. $\nmid \%$ Of National Center for Health Statistics 50 th percentile.

TABLE II-Comparison of univariate logistic models using five different anthropometric indices to predict death

\begin{tabular}{|c|c|c|c|c|c|}
\hline & $\begin{array}{c}\text { Odds ratio } \\
\text { (95\% conf- } \\
\text { dence interval) }\end{array}$ & $\begin{array}{l}\text { Likelihood } \\
\text { ratio (1) } \\
\left(\chi^{2}, 1 \mathrm{df}\right)\end{array}$ & $\begin{array}{c}\text { Hosmer- } \\
\text { Lemeshow } \\
\text { C statistic } \\
\left(\chi^{2}, 3 \mathrm{df}\right)\end{array}$ & $\begin{array}{l}\text { No }(\%) \text { of } \\
\text { deaths in two } \\
\text { highest } \\
\text { risk deciles }\end{array}$ & $\begin{array}{l}\text { Log } \\
\text { likelihood }\end{array}$ \\
\hline $\begin{array}{l}\text { Arm circumference } \\
(\mathrm{cm})\end{array}$ & $\begin{array}{c}0.68 \\
(0.56 \text { to } 0.81)\end{array}$ & $18 \cdot 6^{\star}$ & $2 \cdot 17$ & $15(44)$ & $204 \cdot 96$ \\
\hline $\begin{array}{l}\text { Arm circumference } \\
\text { for age }(\%)\end{array}$ & $\begin{array}{c}0.94 \\
(0.91 \text { to } 0.97)\end{array}$ & $16 \cdot 3^{\star}$ & $2 \cdot 05$ & $14(41)$ & $207 \cdot 28$ \\
\hline Weight for age (\%) & $\begin{array}{c}0.94 \\
(0.93 \text { to } 0.98)\end{array}$ & $15 \cdot 5^{\star}$ & $5 \cdot 41$ & $13(38)$ & $208 \cdot 04$ \\
\hline $\begin{array}{l}\text { Weight for height } \\
(\%)\end{array}$ & $\begin{array}{c}0.96 \\
(0.94 \text { to } 0.99)\end{array}$ & $5 \cdot 6 t$ & 1.72 & $10(29)$ & $217 \cdot 96$ \\
\hline Height for age (\%) & $\begin{array}{c}0.95 \\
(0.90 \text { to } 0.99)\end{array}$ & $5 \cdot 0+$ & $4 \cdot 64$ & $9(26)$ & $218 \cdot 52$ \\
\hline
\end{tabular}

${ }^{\star} \mathrm{p}<0.001 .+\mathrm{p}<0.05$.
Arm circumference, arm circumference for age, and weight for age gave better balance of sensitivity and specificity for predicting death than did other indices (figure). ${ }^{\text {is }}$ The classical cut off points used to define severe malnutrition-namely, $60 \%$ of median weight for age, an arm circumference of $125 \mathrm{~mm}, 85 \%$ of median height for age, and $70 \%$ of median weight for height ${ }^{1-6}$-correspond to specificities of $40 \%, 23 \%, 72 \%$, and $66 \%$ respectively and are not related to any inherent breakpoint in the sensitivity specificity curves.

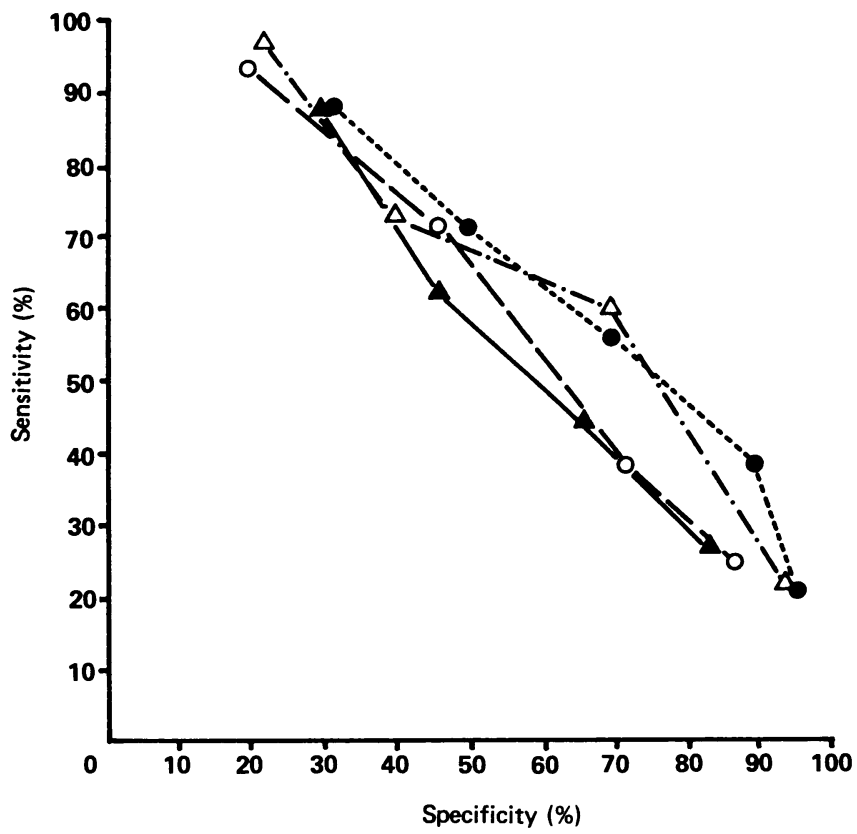

Sensitivity of nutritional indices for different specificities. The curve for arm circumference for age, which was virtually identical with the curve for arm circumference, is not shown. $\triangle-\cdot-. \Delta=$ Weight for age. - - $=$ Arm circumference. $\boldsymbol{\Delta}-\boldsymbol{\Delta}=$ Weight for height. $\mathrm{O}-\mathrm{O}=$ Height for age.

All the anthropometric indices correlated strongly with each other $(p<0.001)$, suggesting that most of the indicators used to estimate the risk of death were closely related. Once arm circumferences, the best univariate predictor of death, had been included in the model the other nutritional indices were tested by bivariate logistic regressions, but none were significantly better at predicting death (table III).

TABLE III-Comparison of bivariate logistic models using arm circumference and one other nutritional index to predict death

\begin{tabular}{|c|c|c|c|c|c|}
\hline & $\begin{array}{l}\text { Coefficient } \\
\quad(\mathrm{SE})\end{array}$ & $\begin{array}{c}\text { Odds ratio } \\
(95 \% \text { confi- } \\
\text { dence interval })\end{array}$ & $\begin{array}{l}\text { No }(\%) \text { of } \\
\text { deaths in two } \\
\text { highest risk } \\
\text { deciles }\end{array}$ & $\begin{array}{c}\text { Log } \\
\text { likelihood }\end{array}$ & $\begin{array}{c}\text { Deviance } \\
\text { from } \\
\text { univariate } \\
\text { model } \\
\left(\chi^{2}, 1 \mathrm{df}\right)\end{array}$ \\
\hline $\begin{array}{l}\text { Arm } \\
\text { circumference } \\
\text { Weight for age }\end{array}$ & $\begin{array}{l}-0.321+(0.141) \\
-0.028(0.019)\end{array}$ & $\begin{array}{l}0.72(0.55 \text { to } 0.96) \\
0.97(0.94 \text { to } 1.00)\end{array}$ & $17(50)$ & $202 \cdot 66$ & $2 \cdot 30$ \\
\hline $\begin{array}{l}\text { Arm } \\
\text { circumference } \\
\text { Weight for height }\end{array}$ & $\begin{array}{l}-0.426 \$(1.123) \\
-0.008(0.018)\end{array}$ & $\begin{array}{l}0.65(0.51 \text { to } 0.83) \\
0.99(0.95 \text { to } 1.02)\end{array}$ & $16(47)$ & $204 \cdot 74$ & 0.22 \\
\hline $\begin{array}{l}\text { Arm } \\
\text { circumference } \\
\text { Height for age }\end{array}$ & $\begin{array}{l}-0.422 \Omega(0.120) \\
-0.018(0.026)\end{array}$ & $\begin{array}{l}0.66(0.52 \text { to } 0.83) \\
0.98(0.93 \text { to } 1.03)\end{array}$ & $17(50)$ & $204 \cdot 5$ & 0.46 \\
\hline
\end{tabular}

$\star$ Difference between $\log$ likelihood of bivariate model and log likelihood of univariate mode using arm circumference alone. $t \mathrm{p}<0 \cdot 05 . \$ \mathrm{p}<0 \cdot 001$.

The possibility that a combination of several nutritional indices, such as those used in certain nutritional classification schemes, could better predict death was tested by multivariate logistic regression analysis. Table IV shows the results: none of these combinations was significantly better at predicting death than arm circumference alone. 
TABLE IV-Comparison of multivariate logistic models using arm circumference and other nutritional indices to predict death

\begin{tabular}{|c|c|c|c|c|c|}
\hline & $\begin{array}{l}\text { Coefficient } \\
\text { (SE) }\end{array}$ & $\begin{array}{c}\text { Odds ratio } \\
(95 \% \text { confi- } \\
\text { dence interval })\end{array}$ & $\begin{array}{l}\text { No (\%) of } \\
\text { deaths in two } \\
\text { highest risk } \\
\text { percentiles }\end{array}$ & $\begin{array}{l}\text { Log } \\
\text { likelihood }\end{array}$ & $\begin{array}{c}\text { Deviance } \\
\text { from } \\
\text { univariate } \\
\text { model } \\
\left(\chi^{2}, 2 \mathrm{df}\right)\end{array}$ \\
\hline $\begin{array}{l}\text { Arm } \\
\text { circumference } \\
\text { Weight for age } \\
\text { Presence of } \\
\text { oedema }\end{array}$ & $\begin{array}{l}-0.312+(0.140) \\
-0.029(0.019) \\
-0.307(0.481)\end{array}$ & $\begin{array}{l}0.73(0.56 \text { to } 0.96) \\
0.97(0.94 \text { to } 1.00) \\
0.73(0.29 \text { to } 1.89)\end{array}$ & $18(53)$ & $204 \cdot 24$ & 0.72 \\
\hline $\begin{array}{l}\text { Arm } \\
\text { circumference } \\
\text { Weight for height } \\
\text { Height for age }\end{array}$ & $\begin{array}{l}-0.4055(0.127) \\
-0.007(0.018) \\
-0.017(0.026)\end{array}$ & $\begin{array}{l}0.67(0.52 \text { to } 0.86) \\
0.99(0.95 \text { to } 1.02) \\
0.98(0.93 \text { to } 1.03)\end{array}$ & $16(47)$ & $204 \cdot 32$ & 0.64 \\
\hline $\begin{array}{l}\text { Arm } \\
\text { circumference } \\
\text { Weight for height } \\
\text { Age }\end{array}$ & $\begin{array}{l}-0.419 \$(0.139) \\
-0.010(0.019) \\
-0.002(0.013)\end{array}$ & $\begin{array}{l}0.66(0.50 \text { to } 0.86) \\
0.99(0.95 \text { to } 1.03) \\
1.0(0.97 \text { to } 1.02)\end{array}$ & $16(47)$ & $204 \cdot 72$ & $0 \cdot 24$ \\
\hline
\end{tabular}

*Difference between log likelihood of bivariate model and log likelihood of univariate model using arm circumference alone. $t \mathrm{p}<0.05 . \oint p<0.01$.

\section{Discussion}

The close relation between the mortality of children during an attack of diarrhoea and their nutritional state on admission to hospital has been mentioned in early studies at the beginning of the century. ${ }^{16}$ Results of the multivariate analysis, however, show that the assessment of malnutrition to evaluate the risk of death can be made simpler than is usually suggested: in our sample arm circumference alone, without correction for age, was a slightly better predictor of death than nutritional indices based on height, weight, and age. A combination of indices, including the presence of oedema, did not significantly improve the predictions. Thus the Waterlow, Wellcome, and McLaren classifications, ${ }^{2.6}$ or any other classification based on such combinations, would not be better at predicting death than arm circumference alone.

In a recent study in the United States Baker et al found that clinical evaluation of nutritional state was as effective as a complete anthropometric assessment with measurement of biochemical indicators of malnutrition in predicting the risk of infection in surgical patients. ${ }^{17}$ Although performed in a very different setting, the results of our study also suggest that a simple measure is as effective as more complex schemes for selecting patients at risk.

Because this study was performed in a hospital for diarrhoeal diseases undetected dehydration in some patients might have affected the accuracy of weight measurements and weight related indices used to estimate nutritional state; however, weight was estimated after correcting for dehydration, and the degree of dehydration on admission did not vary significantly between children who died and those who survived.

Inaccurate maternal reporting of age is more common for children over 1 year old, ${ }^{18}$ a period when growth is slower. Inaccuracies in age in this age group, if not considerable, should not affect appreciably the accuracy of age dependent nutritional indices and their predictive value. Moreover, in a community study of children under 5 years old in rural Bangladesh where the exact date of birth was known the inclusion of age in the model did not significantly improve the predictive value. ${ }^{19}$

The absence of a clear demarcation, in the specificity sensitivity curves, of the traditional cut off points between the different degrees of malnutrition shows their artificial nature, but optimal cut off points for screening children in the community cannot be derived from our data: children used as a control group in a hospital study such as this one cannot be considered to be representative of children living in the community. To define an ideal cut off point for screening children at risk the prevalence of malnutrition in the particular community has to be known, ${ }^{20}$ and the consequences of missing a case of malnutrition or overdiagnosing malnutrition have to be taken into account. ${ }^{21}$

Weight based indices are often considered preferable to arm circumference when screening for malnutrition. ${ }^{22}$ This may be because weight can be estimated very precisely with standard weighing scales whereas arm circumference is difficult to measure precisely. ${ }^{23}$ The precision necessary for screening children at risk of dying, however, has never been adequately evaluated. In this sample the difference between the mean weight of children who died and those who survived was $1.3 \mathrm{~kg}$, which is equivalent to $20 \%$ of the mean weight of the whole sample. The high precision obtainable when measuring weight may therefore be irrelevant in separating these two groups of children.

Arm circumference is largely determined by muscle mass and is closely related to total body protein. Weight is more closely related to total body water, the proportion of which is thought to be abnormally high in malnourished children. ${ }^{24}$ This could affect the relevance of indices based on weight.

Nutritional indices and nutritional classifications have been designed for different purposes. Among these are international comparisons, research on the range of physiological manifestations of malnutrition, and screening children who are at risk of malnutrition for nutritional intervention. When the objective is to reduce deaths associated with malnutrition the relevance of complex classifications is doubtful. Measuring arm circumference is simple and requires little time. It should be preferred to more complex screening schemes for selecting children at a high risk of dying.

\section{References}

1 Gomez F, Galvan RR, Frenk S, Cravioto J, Chavez R, Vasquez J. Mortality in second and third degree malnutrition. I Trop Pediatr 1956;2:77-83.

Wegree JC. Classifcation and definition of protein energy malnutrition. Br Med f 1972;iii 566-9.

Waterlow JC, Ruithauser IHE Malnutrition in man. In: Cravioto J, Hambreus L, Vahlquist B, eds. Early malnutrition and mental development. Uppsala: Almqvist and Wiksell, 1974:13-26. (Symposium of the Swedish Foundation XII.)

4 Waterlow JC, Buzina R, Keller W, Lane JM, Nichaman MZ, Tanner JM. The presentation and use of height and weight data for comparing the nutritional status of groups of children under the age of 10 years. Bull WHO 1977;55:489-98.

McLaren DS, Read WWC. Weight/length classification of nutritional status. Lancet 1975;ii 219-21.

6 Anonymous. Classification of infant malnutrition [Editorial]. Lancet 1970;ii:302-3.

Gopalan C, Rao KSJ. Classifications of malnutrition: their limitations and fallacies. 7 Trop Pediatr $1984 ; 30: 7-10$.

8 World Health Organisation. A manual for the trealment of acute diarrhoea for use by physicians and other senior health workers. SER 80, 2nd rev, 1984. (Programme for control of diarrhoeal diseases.)

9 National Center for Health Statistics. NCHS growth curves for children: birth to 18 years. Hyattsville: US Department of Health, Education, and Welfare, 1977. (Publication No (PHS) Hyattsville:

10 Jelliffe DB. The assessment of nutritional status in the community. WHO Monogr Ser 1966 No 53

11 Kleinbaum DG, Kupper LL, Morgenstern H. Epidemiological research: principles and methods. Belmont: Lifetime Learning Publications, 1982.

12 Leon D, Phillips JF. Analytical program for multivariate operations research on limited capacity computer systems. Dhaka: International Centre for Diarrhoeal Disease Research, Bangladesh, 1983:5-18. (Operations Research Project Documentation Note No 1.)

13 Armitage P. Statistical methods in medical research. Oxford: Blackwell Scientific Publications, 1971 14 Lemeshow S, Hosmer DW. A review of the goodness of fit statistics for use in the development of logistic regression models. Am J Epidemiol 1982:115:92-106.

15 Galen S, Gambino SR. Beyond normality: the predictive value and efficiency of medical diagnosis. New York: Wiley, 1975 .

16 Scrimshaw NS, Taylor CE, Gordon JE. Interaction of nutrition and infection. WHO Monogr Ser $1968 ;$ No 57 .

17 Baker JP, Detsky A, Wesson DE, et al. Nutritional assessment: a comparison of clinical judgment and objective measurements. N Engl f Med 1982;306:969-72.

18 Bairagi R, Aziz KMA, Chowdhury MK, Edmonston B. Age misstatement for young children in rural Bangladesh. Demography 1982;19:447-58.

19 Briend A, Zimicki S. Validation of arm circumference as an indicator of risk of death in children under 5. Nutrition Research (in press).

20 Vecchio TJ. Predictive value of a single diagnostic test for unselected populations. $N$ Engl f Med 1966;274:1171-3.

21 Habicht JP. Some characteristics of indicators of nutritional status for use in screening and surveillance. Am f Clin Nutr 1980;33:531-5.

22 Morley D. Growth monitoring. In: Grant JP, ed. The state of the world's children 1984. New York: UNICEF, Oxford University Press, 1984:77-81.

23 Velzboer MI, Selwyn BJ, Sargent II F, Pollitt E, Delgado F. The use of arm circumference in simplified screening for acute malnutrition by minimally trained health workers. $\mathcal{f}$ Trop Pediatr 1983;29:159-66.

24 McLaren DS, Burman D. Textbook of paediatic nutrition. 2nd ed. Edinburgh: Churchill Livingstone, 1982.

(Accepted 16 May 1986) 